\title{
HEDA'S HYDRA. ON THE ENIGMATIC HYDRA MOTIF ON CHINESE BLUE AND WHITE PORCELAINS, AS IN WILLEM CLAESZ HEDA'S STILL LIFE OF I638
}

Shards of glass, cracked nutshells, oysters carelessly scattered about, a silver cup knocked over - Willem Claesz Heda's pronkstilleven of I638 (fig. I) shows a lush banquet that is toppling into minor chaos. The notion of derangement is mildly irritating, given that the dining table and the stool are bountifully laid out with precious goods. Besides culinary luxuries like wine, lemons, hazelnuts, and olives, imported from warmer regions like the Mediterranean, ${ }^{\prime}$ a broad variety of valuable tableware is also displayed. Treasures from the East, such as the paper cone with rare pepper or the smooth, glossy Chinese porcelain objects, testify to voyages across distant oceans.

\section{Heda's Porcelains}

The unique materiality of porcelain with its shiny-white, translucent, hard body arrived in Europe from the i4th century onwards in a few, exceedingly rare examples. ${ }^{2}$ When the Portuguese established direct trade with the Chinese, porcelain with underglaze cobalt blue decoration became a fashionable luxury at European courts. Later, through the Dutch VOC (Verenigde Oostindische Compagnie), large quantities of porcelain were shipped to Dutch harbours, satisfying the growing demand for the delicate blue and white wares.

The Ming porcelains assembled in Heda's still life represent different wares with different biographies. The plates with the roasted pickerel and guinea fowl are mass-produced kraakware, a type of export porcelain manufactured for foreign markets between 1550 and I650. ${ }^{3}$

The tankard on the other hand is an early example of a type of porcelain commissioned by European merchants following the shape of European tableware. The VOC had successfully ordered butter dishes, mustard pots, vessels for wine, and saltcellars in $1635 .{ }^{4}$ The tankard in Heda's still life must have belonged to the first generation of this new type of export porcelain. A very similar beer mug in Museum De 5000 Morgen in Hoogeveen has recently been linked to the one depicted in Heda's still life. ${ }^{5}$

The Hydra bowl in Heda's still life is the most curious object in the painting, combining kraak design, as can be seen from the inner panelled structure, with a European coat of arms and a Latin motto reading Sapenti Nihil Novum [sic] ('nothing is new to the wise') on the outside. ${ }^{6}$ The shield and banderole are surrounded by Buddhist emblems, auspicious symbols and decorative elements, including lozenges, tassels, lotus blossoms, and beads. Several objects have survived that can be directly linked to Heda's painted bowl. 


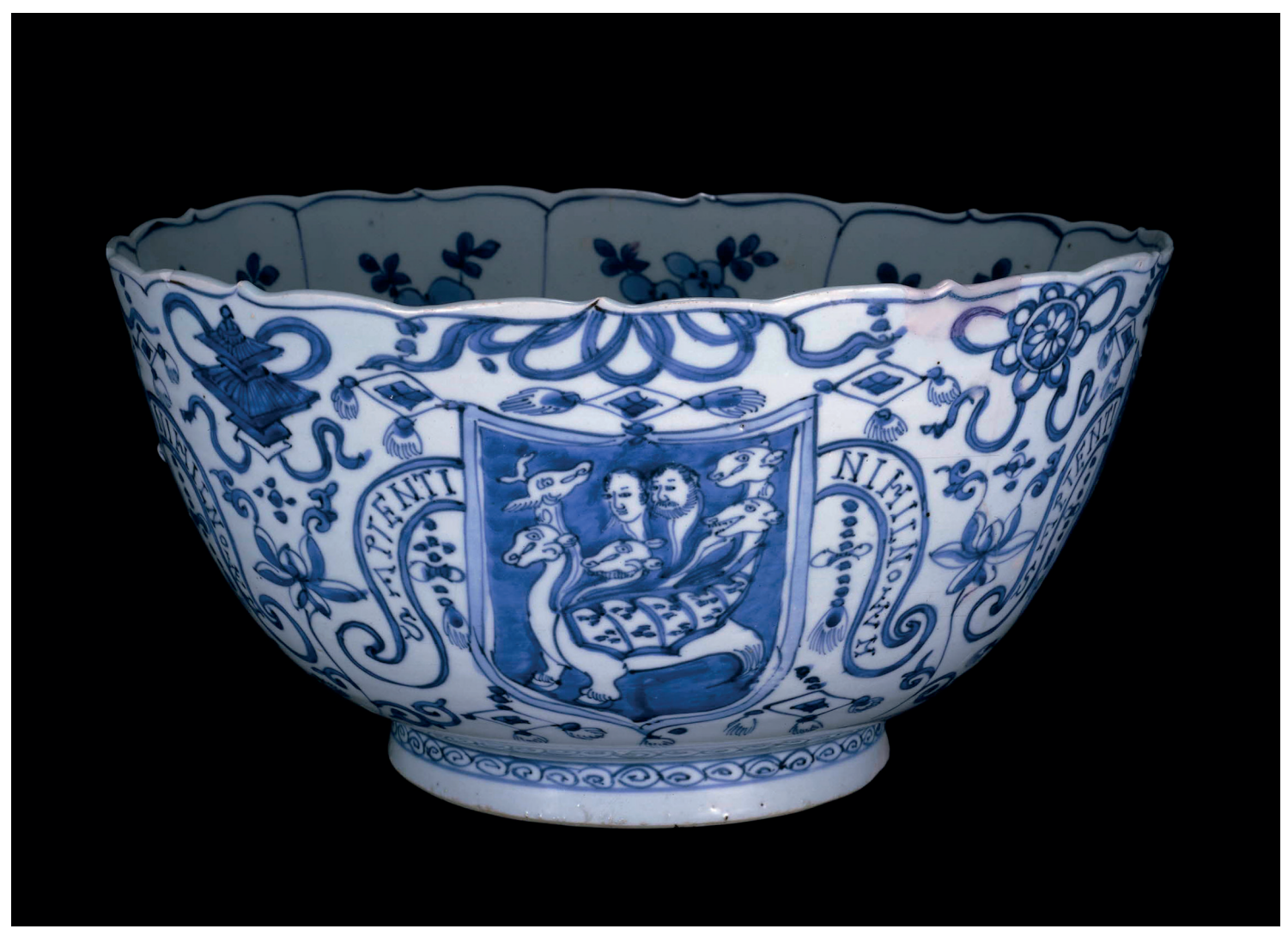

Fig. 2

Passmore bowl, porcelain with cobalt blue underglaze,

h. $17 \mathrm{~cm}$., dia. $34.5 \mathrm{~cm}$., Jingdezhen, China, c. 1600-1620, British Museum, London, inv.no. OA 1957.12-16.19
(I) The so-called Passmore bowl (fig. 2) in the British Museum testifies with its nearly identical design and seemingly similar dimensions to Heda's careful rendering of the porcelain model. A couple of small differences, however, bearing in mind Heda's meticulousness, suggest that the London bowl is not identical to the one in the painting: the varying arrangement of the Hydra's beastly heads, the additional lozenge on the London piece (just above the shield) and the Hydra's wing, which Heda renders blue, while in the London piece it is left white with a cobalt blue contour. (2) In May 2013, a Hydra bowl similar to the Passmore bowl and Heda's model was sold at auction in Germany.7 (3) The pyramidal porcelain ceiling in Santos Palace, Lisbon, comprising more than 260 Chinese porcelains, has yet another Hydra-motif dish: a saucer with the Hydra shield in its well surrounded by kraak panels. ${ }^{8}$ (4) Similar to the Lisbon piece, a charger from the Peabody Essex Museum combines the Hydra shield in the well with surrounding kraak panels. ${ }^{9}$ (5) Another bowl with the Hydra shield in its well can be found in the Gemeentemuseum Arnhem. Here the Buddhist emblems and auspicious symbols are interchanged with vegetal twining ornamentation. ${ }^{\circ}$ (6) A curious fritware bowl from I7th-century Iran in the Victoria \& Albert Museum (fig. 3) emulates a Hydra bowl similar to the one in Heda's painting. In contrast to the Chinese bowls with bracketlobed rims, this one has a flat rim. Reproducing the overall design and impression quite accurately, the Middle Eastern potter nonetheless rendered the bowl to his own interpretation. The looped ribbons haves $\mathrm{a}_{3}$ 07:12:20Am 


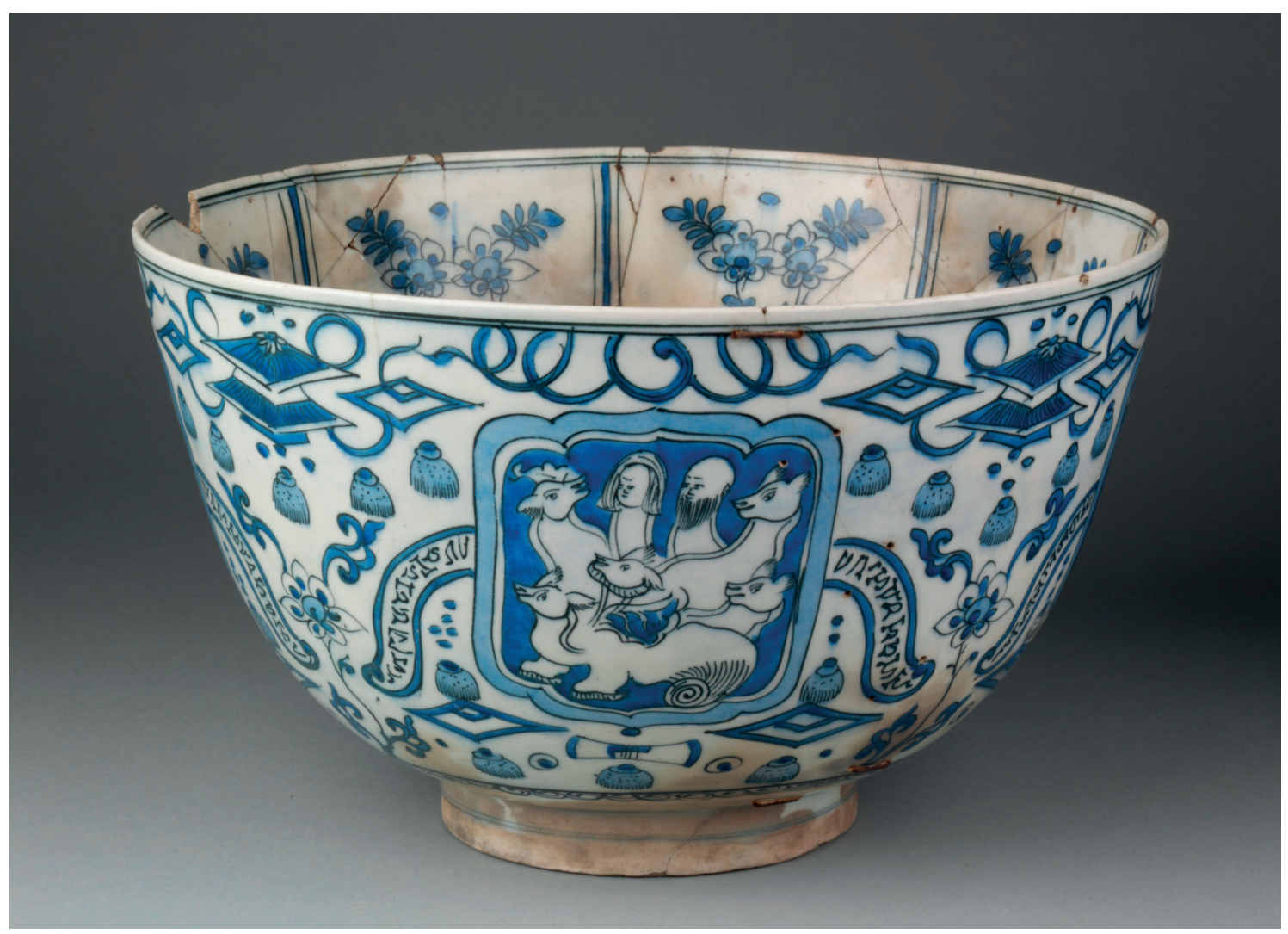

Fig. 3

Bowl of fritware with underglaze painting in blue and black, h. 19.5 cm., dia. 32.5 cm., Iran, 1630-60, Victoria \& Albert Museum, London, inv.no. 2904-1876 strong calligraphic force, the shield is more freely shaped, the decorator introduced a more rhythmic arrangement of the Hydra's heads, and the Latin inscription - presumably illegible to the potter - has mutated into a pseudo-script. (7) Finally, a shard, excavated at the site of the St Augustine convent in Macao, bears the Hydra shield motif. ${ }^{\text {" }}$

The Chinese pieces are most commonly dated around I600-20, placing them in the later Wanli Period of the Ming Dynasty (I368-I644). ${ }^{12}$ The Iranian fritware bowl was probably made later, around I630-I660. One might wonder about the various places these dishes found themselves in the early modern period. How did they travel simultaneously to I7thcentury Netherlands, Portugal and Iran? Thus far no conclusive theory can explain the wide distribution of these wares. Taking a closer look at the iconography might be of help here.

\section{Approaches to the enigmatic Hydra motif}

According to Greek mythology the Hydra, a many-headed, snake-like water beast, lived in the marshes near Lerna, where it terrorised the villagers and killed their livestock. As one of his Twelve Labours, Heracles was sent to kill the monster, but every time he cut off one of its heads two new ones grew back. Only by cauterising the stumps after decapitation could Heracles kill the Lernean Hydra. 
In the porcelains under discussion, the Hydra motif is used in an armorial context. Thus far, though, no individual, family or group could be linked to such a coat of arms or device. The Hydra is not a common motif in heraldic imagery. Still, it can be found in I6th-century sources, e.g., two Hydra devices in the Italian emblem book Imprese Illustri published by Camillo Camilli in 1586 (fig. 4). These devices were chosen by individuals to supplement their family coat of arms. The Hydra serves as a symbol of many-faced evil that grows even stronger while you fight it. Political iconography took up this imagery reinforcing rulership, e.g., in a print of Henri IV of France slaying a Hydra. ${ }^{13}$

The Hydra image served in the early modern period not only in the context of profane power display, but also in religion. It came to symbolise many-headed heresy, with each head representing a different threat to the Catholic Church: reformatory forces, Judaism, Islam, or simply infidels. The Portuguese Inquisition, an instrument against heresy and schism, despatched its envoys to its dominions from Portugal to Mozambique, Brazil and even Macao. Parading in Portuguese cities in I58I and I6I9, the Spanish Habsburg rulers Philip II and Philip III were honoured by the local populace with ephemeral monuments depicting them in their campaign against heresy as Heracles fighting the Hydra. ${ }^{14}$ The many-headed beast became associated even further with religious connotations, linking it to the description in Revelations of the apocalyptic beast of the sea: 'And I stood upon the sand of the sea, and saw a beast rise up out of the sea, having seven heads and ten horns, and upon his horns ten crowns, and upon his heads the name of blasphemy.' (Rev. I3: I; King James Version) This creature's representation was mixed with the iconography of the Lernean Hydra, e.g., in prints by Heinrich Aldegrever (fig. 5), where the Hydra acquires the traits of the apocalyptic monster such as its horns, bear-like claws and lion's mane, all elements from the biblical description. The Hydra is most commonly depicted with seven

\footnotetext{
Fig. 4 (left)

Hydra imprese of Alfonso Sancho, marchese di Grottola, in: Camillo Camilli 1586

Fig. 5

Hercules slaying the Lernean Hydra, Heinrich Aldegrever, engraving on paper, $10.6 \times 6.7 \mathrm{~cm}$., $155^{\circ}$, Rijksmuseum,

Amsterdam, inv.no. RP-P-OB-2703
}
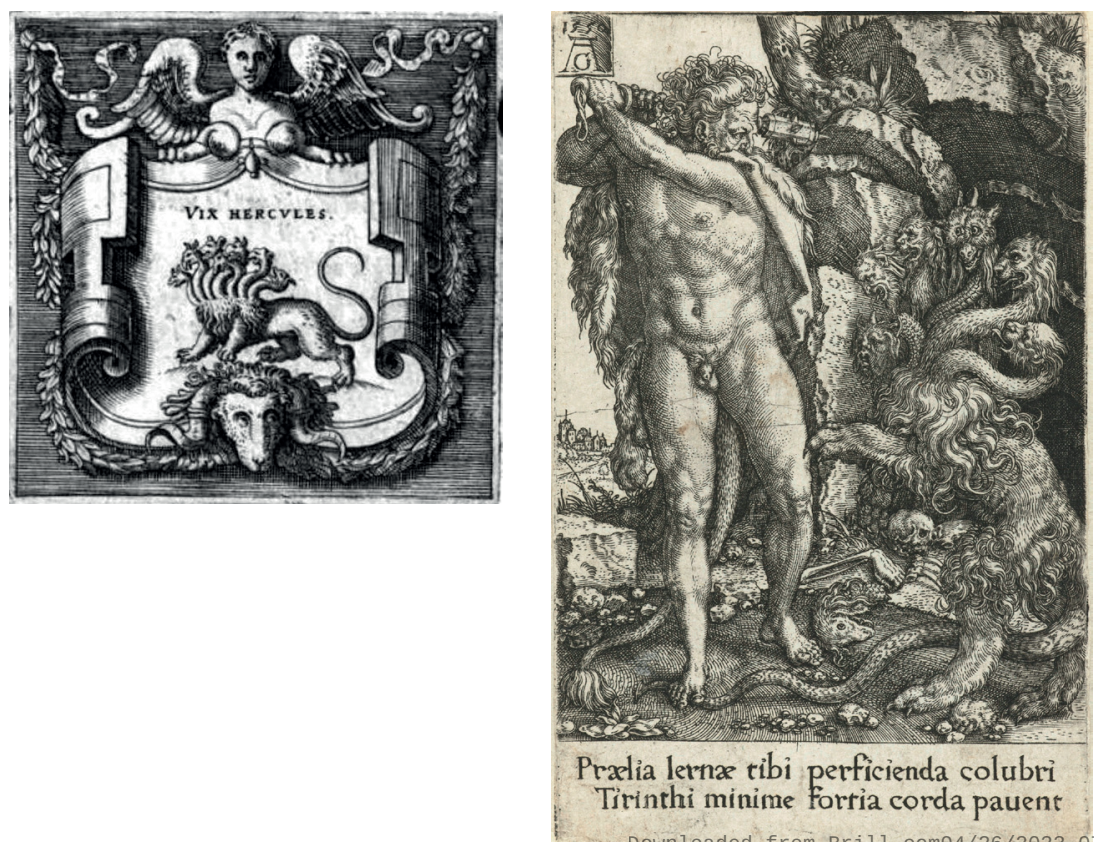
Fig. 6

Carved stone façade,

1620-27, St Paul's

Cathedral, Macao
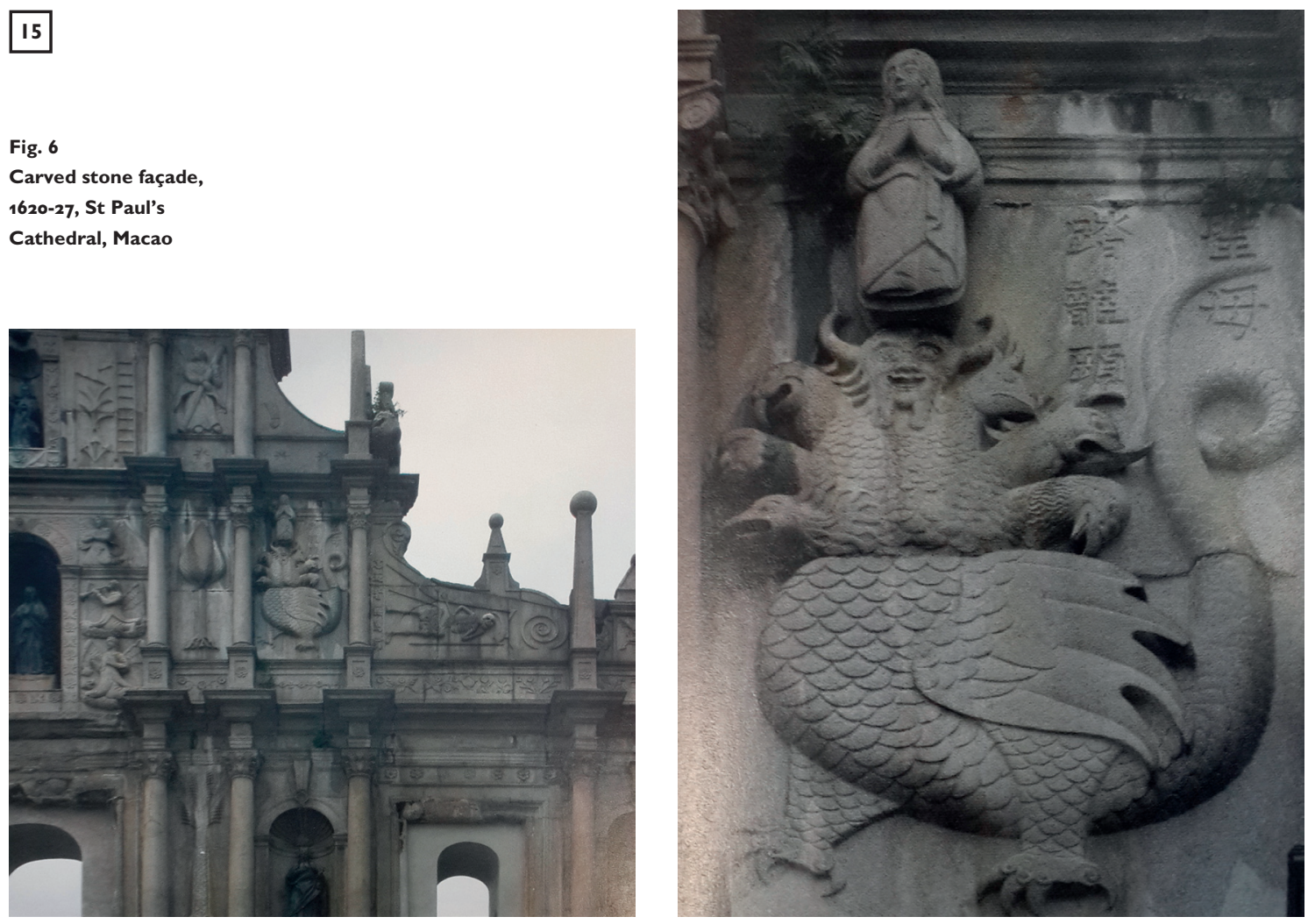

identical heads, as in the Imprese Illustri, but Aldegrever varies them, giving each head unique, monstrous features and even introducing human facial traits.

The façade of the Jesuits' St Paul's Cathedral in Macao shows a pious woman with folded hands standing on a similar Hydra-like monster (fig. 6). The Chinese inscription reads that the 'Holy Mother tramples the Heads of the Dragon'. ${ }^{15}$ Here, the Virgin Mary, the Church and the woman of the Apocalypse are depicted in one, triumphing over evil as described in Revelations. Again there is a variety of monstrous heads, two of them with human-like features. Given that the Hydras on the porcelains also possess a combination of monstrous and humanoid heads, I would link them to this type of visual source combining the imagery of the Lernean Hydra and the apocalyptic monster. The shard found at the convent in Macao, furthermore, could be related to this façade, though the nature of the connection remains unclear.

In the I5th and I6th centuries the Hydra was not purely mythological - the existence of a several-headed dragon-like animal was still debated in contemporary scientific discourse. Naturalists such as Ulisse Aldrovandi and Conrad Gessner included illustrations of the Hydra in their works. Stuffed Hydras, fake creatures mainly concocted from dried fish, were displayed in grand European collections or cabinets of curiosities. ${ }^{16}$ Hydras might have inhabited distant lands that were just being discovered, aligning them with exotic animals like elephanats 023 07:12:20Am 
Fig. 7

19th century facsimile

on paper of the Carta

universal of Diego

Ribero, 1529, $140 \times$

$59 \mathrm{~cm}$., Bibliothèque

Nationale de France
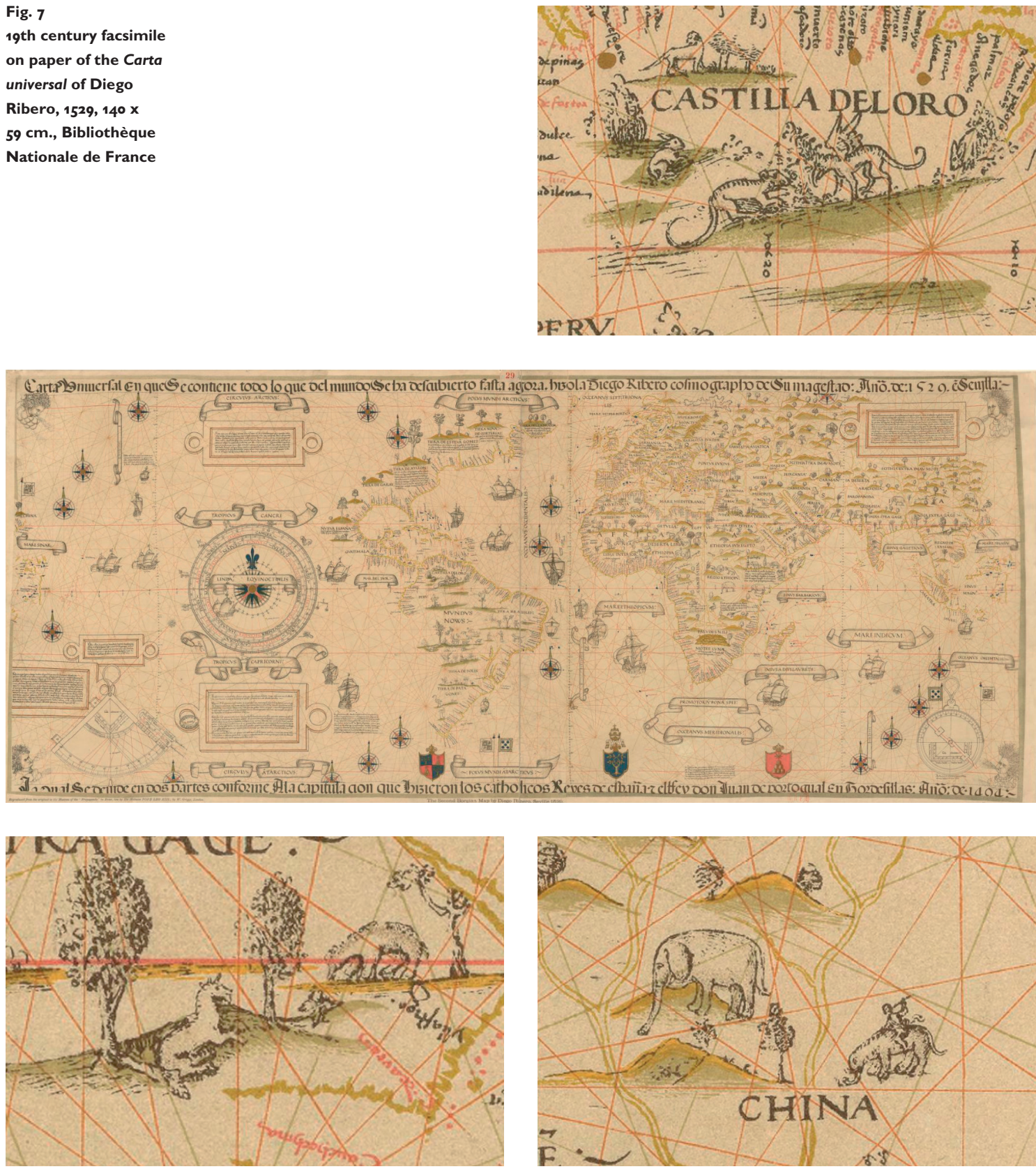
ostriches or rhinos. In Diego Ribero's 529 world map, the new worlds are populated with exotic flora and fauna: real animals like the elephant and mythical creatures such as the unicorn or the gryphon (fig. 7). One might speculate whether the motto Sapienti Nihil Novum was not intended to refer flatteringly to the educated and far-travelled client, who was quite unfazed by these wonders as represented by exotic beasts as well as by the unfamiliar materiality of the porcelains.

\section{Conclusion}

The armorial Hydra porcelains remain mysterious. One can only speculate about the reasons for their early and widespread distribution, as well as their enigmatic imagery and motto. The occurrence of the pieces and motif in Santos Palace and in Portuguese Macao could suggest a Portuguese commissioner. Might the porcelains have been ordered in the context of the construction of Macao's St Paul's Cathedral? ${ }^{17}$ This would not explain, of course, the two pieces that must have passed through I7thcentury Netherlands and Iran.

It has been argued here that during the early modern period the Hydra was a complex, hybrid creature, composed of mythical, biblical and faunal identities, that was linked to profane and religious power discourses as well as to the sciences. Its iconography in the precise context of the porcelains, however, has not yet been fully deciphered.

- Lucy Jarman is a graduate student of art history at the Free University in Berlin and Coordinator of the research and fellowship programme 'Connecting Art Histories in the Museum'.

\section{I T E RAT UR E}

Camillo Camilli (ed.), Girolamo Porro (art.), Imprese illustri di diuersi co i discorsi, vol. 3, 1586, publ. by Ziletti, Venice, Complutense University Library, Madrid.

Teresa Canepa, Silk, porcelain and lacquer: China and Japan and their trade with Western Europe and the New World I50o-I644: A survey of documentary and material evidence, Leiden, 2015. [doctoral thesis]

Karina H. Corrigan, Jan van Campen and Femke Diercks, Asia in Amsterdam: The culture of luxury in the Golden Age, Peabody Essex Museum/Rijksmuseum, Salem, MA/Amsterdam, 2015. [exh. cat.]

Paula Findlen, 'Inventing nature: commerce, art, and sciences in the early cabinet of curiosities', in: Paula Findlen and P. Smith (eds.), Merchants \& marvels:

Commerce, science and art in early modern Europe, Routledge, New York, 2002, pp. 297-323.

Jessica Harrison-Hall, Ming Ceramics: A catalogue of the late Yuan and Ming ceramics in the British Museum, British Museum Press, London, $200 \mathrm{I}$.

Stephen Hartog, Pronken met oosters porselein, Gemeentemuseum, Arnhem, I990. [exh. cat.]

Julie Berger Hochstrasser, Still life and trade in the Dutch Golden Age, Yale University Press, New Haven/London, 2007.

Jean Michel Massing, 'From Marco Polo to Manuel I: the European fascination with Chinese porcelain', in: J. Levenson (ed.), Encompassing the globe: Portugal and the world in the I6th \& I7th centuries: essays, Arthur M. Sackler Gallery, Washington, DC, 2007.

Milton D. Pacheco, 'Greek mythology at the service of the Portuguese inquisition: 
The case of Hercules and the Hydra of Lerna', Athens Journal of Mediterranean Studies I, I (2015), pp. 25-44.

Maura Rinaldi, Kraak porcelain: A moment in the history of trade, Bamboo, London, 1989.

William R. Sargent and Rose Kerr, Treasures of Chinese Export Ceramics from the Peabody Essex Museum, Peabody Essex Museum, Salem, MA, 2012.

\section{NOTES}

* I would like to express my sincere gratitude to Ching-Ling Wang and Jan van Campen for their valuable advice, encouragement, and support.

I See Hochstrasser 2007.

2 See Massing 2007: 226.

3 Sargent and Kerr 2012: 97.

4 Corrigan, van Campen and Diercks 2015: 264-7.

5 Idem. I wish to thank Dr. Ching-Ling Wang for bringing this piece to my attention.

6 For ideas on the motto's meaning, see Sargent and Kerr 2012: IoIf.

7 Nagel Auktionen, Stuttgart, IO-II May 2013, auction 695, lot 46. Its authenticity needs to be confirmed though, as Jan van Campen kindly pointed out to me.

8 Canepa 2015: I43 and notes II2, II3.

9 Inv.no. E84086. Sargent and Kerr 20I2: IOI-3.

Io Inv.no. AB7979, Harthog I990: 44f.

II Macao Museum, inv.no. SA/95_587, published in Canepa 2015: 269. Sargent and Kerr 2012: I03, mention another piece associated with the armorial Hydra porcelains, sold at a 2000 Boston auction.

12 Harrison-Hall 200I: 300; Sargent and Kerr 2012: IOI. The Santos Palace dish is dated earlier, around 1575-1605 (Rinaldi 1989: 87). The piece in Arnhem is dated I573-I6I9 (Harthog 1990: 44).

I3 Léonard Gaultier, I6th century, Fitzwilliam Museum, Cambridge, inv.no. P.7159-R.

I4 Pacheco 2015.

15 Canepa 2015: 273, note 869.

I6 Findlen 2002: 307ff.

I7 An idea raised by Sargent and Kerr 20I2: I03. 